The University of Maine

\title{
DigitalCommons@UMaine
}

Earth Science Faculty Scholarship

Earth Sciences

4-1-2011

\section{Holtite and Dumortierite from the Szklary Pegmatite, Lower Silesia, Poland}

\author{
A. Pieczka \\ Edward S. Grew \\ University of Maine - Main, esgrew@maine.edu \\ L. A. Groat \\ R.J. Evans
}

Follow this and additional works at: https://digitalcommons.library.umaine.edu/ers_facpub Part of the Earth Sciences Commons

\section{Repository Citation}

Pieczka, A.; Grew, Edward S.; Groat, L. A.; and Evans, R. J., "Holtite and Dumortierite from the Szklary Pegmatite, Lower Silesia, Poland" (2011). Earth Science Faculty Scholarship. 42.

https://digitalcommons.library.umaine.edu/ers_facpub/42 


\title{
Holtite and dumortierite from the Szklary Pegmatite, Lower Silesia, Poland
}

\author{
A. Pieczka ${ }^{1}$, E. S. Grew ${ }^{2}$, L. A. Groat ${ }^{3}$ and R. J. Evans ${ }^{3}$
}

1 Department of Mineralogy, Petrography and Geochemistry, AGH - University of Science and Technology, Mickiewicza 30, 30-059 Kraków, Poland

2 Department of Earth Sciences, University of Maine, 5790 Bryand Global Sciences Center, Orono, Maine 044695790, USA

3 Department of Earth and Ocean Sciences, University of British Columbia 6339 Stores Road, Vancouver, British Columbia V6T IZ4, Canada

[Received 24 November 2010; Accepted 30 March 2011]

\section{ABSTRACT}

The Szklary holtite is represented by three compositional varieties: (1) Ta-bearing (up to 14.66 wt.\% $\mathrm{Ta}_{2} \mathrm{O}_{5}$ ), which forms homogeneous crystals and cores within zoned crystals; (2) Ti-bearing (up to $3.82 \mathrm{wt} . \% \mathrm{TiO}_{2}$ ), found as small domains within the core; and (3) Nb-bearing (up to 5.30 wt.\% $\mathrm{Nb}_{2} \mathrm{O}_{5}$, ) forming the rims of zoned crystals. All three varieties show variable $\mathrm{Sb}+\mathrm{As}$ content, reaching 19.18 wt. $\% \mathrm{Sb}_{2} \mathrm{O}_{3}$ (0.87 Sb a.p.f.u.) and 3.30 wt.\% $\mathrm{As}_{2} \mathrm{O}_{3}(0.22$ As a.p.f.u.) in zoned Ta-bearing holtite, which constitutes the largest $\mathrm{Sb}+\mathrm{As}$ content reported for the mineral. The zoning in holtite is a result of $\mathrm{Ta}-\mathrm{Nb}$ fractionation in the parental pegmatite-forming melt together with contamination of the relatively thin Szklary dyke by Fe, Mg and Ti. Holtite and the As- and Sb-bearing dumortierite, which in places overgrows the youngest Nb-bearing zone, suggest the following crystallization sequence: Ta-bearing holtite $\rightarrow$ Ti-bearing holtite $\rightarrow$ Nb-bearing holtite $\rightarrow$ As- and Sb-bearing, (Ta,Nb,Ti)-poor dumortierite $\rightarrow$ As- and Sb-dominant, (Ta,Nb,Ti)-free dumortierite-like mineral (16.81 wt. $\% \mathrm{As}_{2} \mathrm{O}_{3}$ and 10.23 wt. $\left.\% \mathrm{Sb}_{2} \mathrm{O}_{3}\right)$ with $(\mathrm{As}+\mathrm{Sb})>\mathrm{Si}$. The last phase is potentially a new mineral species, $\mathrm{Al}_{6} \square \mathrm{B}(\mathrm{Sb}, \mathrm{As})_{3} \mathrm{O}_{15}$, or $\mathrm{Al}_{5} \square_{2} \mathrm{~B}(\mathrm{Sb}, \mathrm{As})_{3} \mathrm{O}_{12}(\mathrm{OH})_{3}$, belonging to the dumortierite group. The Szklary holtite shows no evidence of clustering of compositions around 'holtite I' and 'holtite II'. Instead, the substitutions of $\mathrm{Si}^{4+}$ by $\mathrm{Sb}^{3+}+\mathrm{As}^{3+}$ at the $\mathrm{Si} / \mathrm{Sb}$ sites and of $\mathrm{Ta}^{5+}$ by $\mathrm{Nb}^{5+}$ or $\mathrm{Ti}^{4+}$ at the $\mathrm{Al}(1)$ site suggest possible solid solutions between: (1) (Sb,As)-poor and (Sb,As)-rich holtite; (2) dumortierite and the unnamed $(\mathrm{As}+\mathrm{Sb})$-dominant dumortierite-like mineral; and (3) Ti-bearing dumortierite and holtite, i.e. our data provide further evidence for miscibility between holtite and dumortierite, but leave open the question of defining the distinction between them. The Szklary holtite crystallized from the melt along with other primary $\mathrm{Ta}-\mathrm{Nb}-(\mathrm{Ti})$ minerals such as columbite-(Mn), tantalite-(Mn), stibiotantalite and stibiocolumbite as the availability of Ta decreased. The origin of the parental melt can be related to anatexis in the adjacent Sowie Mountains complex, leading to widespread migmatization and metamorphic segregation in pelitic-psammitic sediments metamorphosed at $390-380$ Ma.

Keywords: holtite, dumortierite, Szklary pegmatite, Poland, electron microprobe analyses, solid solutions.

\section{Introduction}

Holtite is a very rare Ta- and Sb-bearing aluminium borosilicate belonging to the dumor-

*E-mail: pieczka@agh.edu.pl

DOI: 10.1180/minmag.2011.075.2.303 tierite group, known from pegmatites at only three localities worldwide. The mineral was first identified by Pryce (1971) in pegmatite specimens from an alluvial tin deposit near Greenbushes, southwestern Western Australia; Voloshin et al. (1977) found holtite in a pegmatite at Mount Vasin-Myl'k, Voron'i Tundry, Kola Peninsula, 
Russia, and Pieczka and Marszałek (1996) described the mineral from a pegmatite at Szklary in Lower Silesia, Poland.

Hoskins et al. (1989) obtained a formula for holtite from the type locality of $\left(\mathrm{Si}_{2.25} \mathrm{Sb}_{0.75}\right) \mathrm{B}\left[\mathrm{Al}_{6}\left(\mathrm{Al}_{0.43} \mathrm{Ta}_{0.27} \square_{0.30}\right)\right.$ $\mathrm{O}_{15}(\mathrm{O}, \mathrm{OH})_{2.25}$, and discussed two main substitutions, $\mathrm{Sb}^{3+}+\square \rightarrow \mathrm{Si}^{4+}+\mathrm{OH}^{-}$and $3 / 5 \mathrm{Ta}^{5+}+{ }^{2} / 5 \square$ $\rightarrow \mathrm{Al}^{3+}$, incorporating $\mathrm{Sb}^{3+}$ in triangular pyramidal coordination at sites close to the tetrahedral sites and $\mathrm{Ta}^{5+}$ at the $\mathrm{Al}(1)$ octahedral site of the dumortierite-holtite structure. Voloshin et al. (1987) recognized low-Sb 'holtite I' and high-Sb 'holtite II' in the material from the Kola Peninsula. However, Locock et al. (2006) discouraged use of these terms because: (1) $\mathrm{Si}$ is dominant at the tetrahedral sites in both varieties; (2) there are no known structural differences between them; and (3) the Commission of New Minerals, Nomenclature and Classification of the International Mineralogical Association had not approved such usage.

Groat et al. (2009) presented structural results of holtite from all of the known occurrences, along with a discussion on substitution and ordering in the holtite structure. Assuming the substitutions presented above are the only significant ones in relating dumortierite compositions to holtite compositions, Groat et al. (2009) gave a general holtite stoichiometry of $\mathrm{A}_{7}-(5 x+y+z) / 3(\mathrm{~T} \mathrm{a}, \mathrm{N} \mathrm{b})_{x} \square(2 x+y+z) / 3$ $\mathrm{BSi}_{3-y}(\mathrm{Sb}, \mathrm{As})_{y} \mathrm{O}_{18-y-z}(\mathrm{OH})_{z}$, where $x$ denotes the total number of pentavalent cations, $y$ is the total amount of $\mathrm{Sb}+\mathrm{As}$, and $z$ is the total amount of $\mathrm{OH}$, with $z \leqslant \mathrm{y}$. This formula does not take into account divalent and tetravalent cations at the $\mathrm{Al}(1)$ site or substitutions at the $\mathrm{Si}$ or $(\mathrm{Sb}, \mathrm{As})$ sites of the dumortierite-holtite structure. Moreover, Groat et al. (2009) noted that their crystalstructure refinements did not reveal any differences in cation ordering that might distinguish 'holtite I' from 'holtite II'. Given also that the two varieties do not qualify as distinct species according to the dominant-valency rule (Hatert and Burke, 2008), Groat et al. (2009) advised that "use of the terms holtite I and holtite II be discontinued".

There are relatively few analyses of holtite and no studies sufficiently systematic to fully characterize holtite composition from any one locality. However, the compositional variation in the Voron'i Tundry holtite and zoning in the Szklary holtite reported by Voloshin et al. (1977, 1987) and Pieczka (2010), respectively, clearly point to the need for systematic studies of holtite from each locality. Such chemical characterization could also provide information about stages of holtite crystallization in the geochemical evolution of pegmatites. In this paper, we present a systematic chemical study of the Szklary holtite and coexisting As- and Sbbearing dumortierite, both of which show extensive compositional variations. These data can be applied to examining the complex relationships between holtite and dumortierite. For the purposes of description of these two dumortierite-group minerals from the Szklary pegmatite, compositions with $\mathrm{Ta}+\mathrm{Nb}+\mathrm{Ti}$ $>0.25$ atoms per formula unit (a.p.f.u.) are being called holtite and compositions with $\mathrm{Ta}+\mathrm{Nb}+\mathrm{Ti}$ $<0.1$ a.p.f.u., dumortierite.

\section{Geological setting}

The Szklary massif is situated $\sim 60 \mathrm{~km}$ south of Wrocław and $6 \mathrm{~km}$ north of Zabkowice Ślaskie in the southern part of the Mississippian Niemcza shear zone (Fig. 1). The zone extends along the eastern edge of the Sowie Mountains block in the northeastern part of the Bohemian Massif (the Central Sudetes and the Fore-Sudetic block, southwestern Poland). The Szklary massif is one of several small bodies of serpentinized ultramafic and mafic rocks that rim the Sowie Mountains gneissic complex, considered parts of a tectonically fragmented Sudetic ophiolite suite (Majerowicz and Pin, 1986) $\sim 420$ Ma old (Oliver et al., 1993), composed of weakly serpentinized harzburgites, lherzolites and pyroxenites containing enclaves of amphibolites and rodingites. The serpentinites are crosscut by numerous aplite, and less commonly, lamprophyre veins. The Szklary pegmatite ( 390 Ma, $\mathrm{Pb}-\mathrm{U}-\mathrm{Th}$ dating of cheralite; Pieczka, unpubl. data) is similar to pegmatites in the nearby Sowie Mountains gneissic complex with respect to the mode of occurrence, internal structure, mineral composition and age of formation.

In the Sowie Mountains complex, metamorphism of pelitic-psammitic sediments reached upper amphibolite facies and led to widespread migmatization and metamorphic segregation. Intrusion of granitic magma during uplift of the Sowie Mountains complex at 374-380 Ma (van Breemen et al., 1988, Timmermann et al., 2000) led to the formation of dykes and veins of pegmatite containing abundant black tourmaline and ranging in 

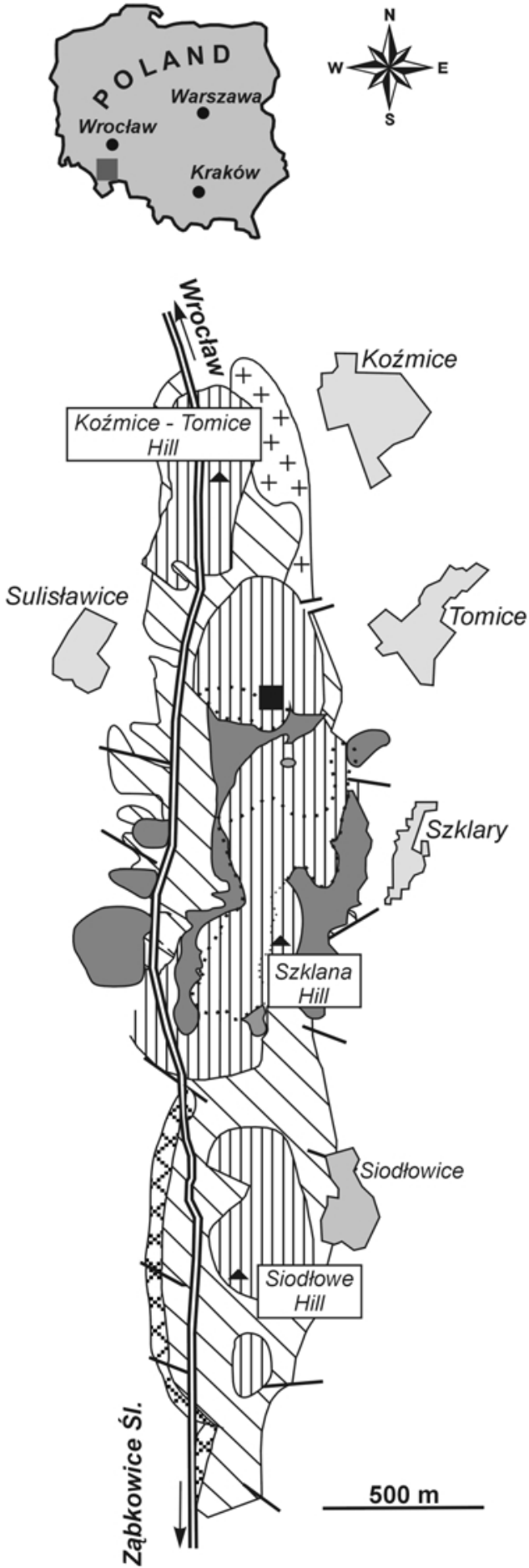

FIG. 1. Geological sketch of the Szklary massif (after Niśkiewicz, 1967, Michalik, 2000).

\section{LEGEND:}

$\Delta \nabla$ - serpentinite eluvium

ПD - serpentinite

- slag dumps from Ni smelters

XX - amphibolite

${ }^{+}{ }_{+}^{+}+$- Niemcza-zone granitoids

- faults

.... - open pits

= - highway Wrocław - Ząbkowice Śląskie

- pegmatite locality

composition from the muscovite to the rare element classes.

\section{The Szklary holtite-bearing pegmatite}

The Szklary pegmatite is exposed in one of the open pits of an abandoned silicate nickel mine, and it is the only such dyke reported in the Szklary serpentinite massif. The pegmatite is placed in the REE subclass of the muscoviterare-element (MSREL) class in the pegmatite classification of Černý and Ercit (2005), because xenotime, cheralite and two unidentified REEbearing phases are relatively common in an early stage of the pegmatite crystallization. In addition, there is no evidence for concentration of $\mathrm{Li}$ and Cs in the pegmatite.

The pegmatite dyke is zoned, consisting of an outer (border) zone composed of graphic intergrowths of albite and quartz, biotite aggregates altered to clinochlore, and black tourmaline. Inward from the border zone, perthitic microcline gradually replaces albite, and the pegmatite grades into a coarse-grained inner zone containing more muscovite and tourmaline, but negligible biotite. The axial part of the inner zone consists of graphic intergrowths of microcline and quartz with occasional nests of black tourmaline. A quartz core is absent.

Dyke feldspars are commonly enriched in phosphorus (0.5-0.6 wt.\% $\left.\mathrm{P}_{2} \mathrm{O}_{5}\right)$. K-feldspars contain $0.13-0.20 \mathrm{wt} . \% \mathrm{Rb}$ and their $\mathrm{K} / \mathrm{Rb}$ ratio ranges from $\sim 90$ to 60 . Tourmaline is commonly represented by dark, $\mathrm{Fe}^{3+}$-bearing, Li-free inter- 
mediate members of the schorl-dravite series (Pieczka and Kraczka, 1996) or, much less frequently, by blue dravite representing a transitional member among the dravite, schorl and olenite end-members (Pieczka, 2007).

Aggregates of holtite crystals, up to $5 \mathrm{~mm}$ in size and creamy-white to yellow, yellow with a brownish tint and yellowish-grey in colour, are generally found in the inner zone of the dyke among crystals of microcline, quartz and black tourmaline; holtite is less common within aggregates of Mn-bearing oxide minerals or as inclusions in quartz. Holtite crystals range from prismatic and acicular to asbestiform and are up to $1 \mathrm{~mm}$ long and to $50 \mu \mathrm{m}$ in diameter, though usually they are smaller. Holtite is associated with stibiocolumbite and microcline having numerous disseminated inclusions of native antimony, native bismuth, paradocrasite, stibarsen and less commonly native arsenic. Locally, in interstices between holtite crystals, stibiocolumbite forms larger aggregates enclosing holtite (Fig. 2). Stibiotantalite has never been found in close proximity to holtite in the pegmatite.

Rare chrysoberyl occurs within muscovite aggregates, and less commonly in the graphic intergrowths of feldspars with quartz. It forms single tabular or twinned crystals on $\{130\}$, usually a few millimeters in size, light green to yellowish green, transparent to translucent, in places intergrown with xenotime or zircon. No beryl has been found either within crystals of
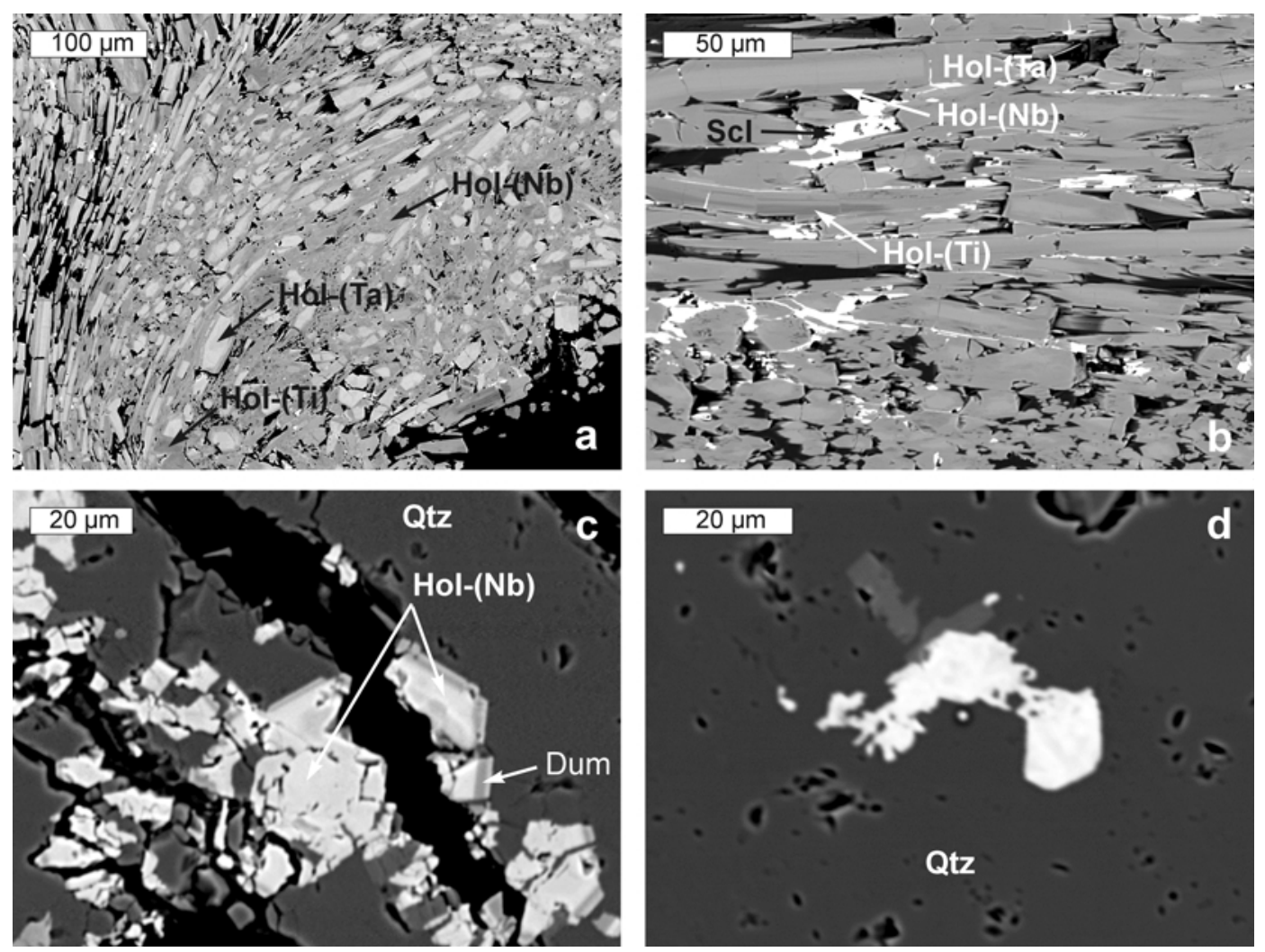

FIG. 2. Representative BSE images of holtite and dumortierite in the Szklary pegmatite: $(a)$ crosswise sections of holtite showing Ta-bearing core and Nb-bearing rim; $(b)$ longitudinal sections of zoned holtite with streaks of Tibearing holtite (dark grey) and stibiocolumbite in interstices among holtite crystals; (c) crystal of Nb-bearing holtite overgrown by As- and Sb-bearing dumortierite surrounded by quartz; $(d)$ inclusions in quartz of an extremely (As,Sb)-enriched dumortierite-like phase containing negligible Ta, Nb and Ti. Abbreviations: Hol-(Ta) - Ta-bearing holtite, Hol-(Nb) - Nb-bearing holtite, Hol-(Ti) - Ti-bearing holtite, Scl - stibiocolumbite, Dum - dumortierite,

Qtz - quartz. 
chrysoberyl or anywhere else in the Szklary dyke. Although the presence of cordierite in the border zone suggests that the pegmatite has been affected by metamorphism, we doubt that chrysoberyl formed by the breakdown of beryl + alkali feldspar reported in metamorphosed pegmatites elsewhere (Franz and Morteani, 1984). Instead, we suggest that chrysoberyl crystallized directly from an anatectic melt. A talc + chlorite + vermiculite contact zone up to $\sim 10 \mathrm{~cm}$ thick between the pegmatite on one side and serpentinite or amphibolite on the other (Pieczka, 2000) could be an altered skarn formed by reaction between the melt and country rocks, resulting in loss of $\mathrm{SiO}_{2}$ and increase of $\mathrm{Al}_{2} \mathrm{O}_{3}$ in the melt, thereby favouring the crystallization of chrysoberyl.

Based on conditions of metamorphism in the Sowie Mountains complex (from 5-7 kbar and $500-600^{\circ} \mathrm{C}$ to $4-5 \mathrm{kbar}$ and $620-670^{\circ} \mathrm{C}$ to $700-730^{\circ} \mathrm{C}$; Żelaźniewicz, 1987, 1990), and the same age of the metamorphic events (374-380 Ma; van Breemen et al., 1988; Timmermann et al., 2000) as the age of the Szklary pegmatite, we conclude that the Szklary dyke represents an injection of mobilized anatectic melt during a significant HT-MP thermal event into a part of the Sudetic ophiolite currently corresponding to the Szklary massif, which in the Late Devonian was already in contact with the Sowie Mountains complex (Żelaźniewicz, 1990).

\section{Analytical methods and formula calculation}

Compositions of zoned holite crystals were analysed at the Inter-Institute Analytical Complex for Minerals and Synthetic Substances of the University of Warsaw using a Cameca SX-100 electron microprobe (EMP) operating in wavelength-dispersive spectroscopic (WDS) mode under the following conditions: accelerating voltage $-15 \mathrm{kV}$, beam current $-20 \mathrm{nA}$, peak count-time $-20 \mathrm{~s}$, background time $-10 \mathrm{~s}$, beam diameter $-1-2 \mu \mathrm{m}$. The following standards, analytical lines and crystals were used: $\mathrm{Al}$ -

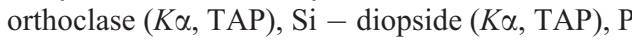
- apatite $(K \alpha, \mathrm{PET}), \mathrm{Sc}-$ pure Sc $(K \alpha, \mathrm{PET}), \mathrm{Ti}$ - rutile ( $K \alpha$, LIF), $\mathrm{Fe}-$ hematite ( $K \alpha, \mathrm{LIF}), \mathrm{As}-$ GaAs ( $L \alpha, \mathrm{TAP}), \mathrm{Nb}-$ pure $\mathrm{Nb}(L \alpha, \mathrm{PET}), \mathrm{Sb}-$ InSb ( $L \beta, \mathrm{PET}), \mathrm{Ta}-$ pure Ta $(M \alpha, \mathrm{TAP})$. The amounts of Mg, Mn, Zr, Sn, W and Bi were below detection using WDS. Compositions of homogeneous holtite (WPH) were obtained at the University of British Columbia using a Cameca
SX-50 microprobe (WDS mode) with the following operating conditions: accelerating voltage $-20 \mathrm{kV}$, beam current $-20 \mathrm{nA}$, peak count-time $-20 \mathrm{~s}$, background time $-10 \mathrm{~s}$, beam diameter $-10 \mu \mathrm{m}$. The following standards and X-ray analytical lines were used: kyanite $\mathrm{Al}(K \alpha), \mathrm{Si}(K \alpha)$; apatite - $\mathrm{P}(K \alpha)$, pure $\mathrm{Sc}-$ $\operatorname{Sc}(K \alpha)$, rutile - $\operatorname{Ti}(K \alpha)$, synthetic fayalite $\mathrm{Fe}(K \alpha)$, tennantite - $\operatorname{As}(K \alpha)$, columbite $\mathrm{Nb}(L \alpha)$, tetrahedrite $-\mathrm{Sb}(L \alpha)$ and microlite $\operatorname{Ta}(M \alpha)$. Data reduction was done with the 'PAP' procedure (Pouchou and Pichoir, 1985) in both laboratories.

Most analyses gave acceptable totals ranging from 97.94 to $100.90 \mathrm{wt} . \%$; an exception is WPH holtite, for which totals range from 93.85 to 96.62 wt.\%. The low totals could have resulted from infiltration of epoxy between very fine holtite fibres in this sample, creating a situation analogous to epoxy soaking very finely porous materials (Sorbier et al., 2004; Grew et al., 2008), in which analytical totals decreased because the target material was diluted by epoxy hit by the relatively wide $10 \mu \mathrm{m}$ electron beam used at the University of British Columbia. This problem appears to have been averted at the University of Warsaw using a 1-2 $\mu \mathrm{m}$ beam, sufficiently narrow to fit on the holtite crystals without hitting epoxy.

Holtite is a mineral the formula of which is very difficult to calculate due to vacancies present not only at the cationic, but also at the anionic sites. Therefore all analyses were normalized by iteration to $(\mathrm{O}+\mathrm{OH})=(18-\mathrm{As}-\mathrm{Sb})$ a.p.f.u. Assuming $1.000 \mathrm{~B}$ a.p.f.u. and $\mathrm{OH}^{-}$to be $=$ $(\mathrm{Sb}+\mathrm{As})$, i.e. $\mathrm{z}=y$, which gave reasonable $\mathrm{H}_{2} \mathrm{O}$ contents for holtite from Greenbushes and Voron'i Tundry (Groat et al., 2009), these authors' formula for holtite simplifies to $\mathrm{A}_{7-(5 x+2 y) / 3(\mathrm{~T} \mathrm{a}, \mathrm{N} \mathrm{b})} \square(2 x+2 y) / 3$ $\mathrm{BSi}_{(3-y)}(\mathrm{Sb}, \mathrm{As})_{y} \mathrm{O}_{18-2 y}(\mathrm{OH})_{y}$. Because the sum $\mathrm{Si}+\mathrm{P}+\mathrm{As}+\mathrm{Sb}$ is always $<3$ a.p.f.u., we have assumed that $\mathrm{Al}$ also occupies a tetrahedral site and have added sufficient $\mathrm{Al}$ to make up the deficiency, i.e. $\mathrm{Si}+\mathrm{P}+\mathrm{As}+\mathrm{Sb}+{ }^{\mathrm{IV}} \mathrm{Al}=3$. This assumption is supported by structural evidence for tetrahedrally coordinated $\mathrm{Al}$ in dumortierite, e.g. Alexander et al. (1986) reported up to $0.15{ }^{\mathrm{IV}} \mathrm{Al}$ a.p.f.u. substituting for $\mathrm{Si}^{4+}$ in some Fe- and Ti-poor samples, and Fuchs et al. (2005) found a similar content of $0.15-0.17^{\mathrm{IV}} \mathrm{Al}$ a.p.f.u. in two samples of dumortierite from Lower Austria. The vacancy at the octahedral sites was calculated from a modified version of the 
relationship given by Groat et al. (2009) and taking into account various divalent and tetravalent cations present in the holtite. We have assumed that the small amount of Fe present (mostly $<0.4$ wt.\% $\mathrm{FeO}$, and none $>0.77$ wt.\% $\mathrm{FeO}$, Table $1 a)$ is entirely $\mathrm{Fe}^{2+}$ because $\mathrm{Fe}^{3+}$ contents are not significant in associated primary $\mathrm{Nb}$-Ta oxides in the pegmatite (Pieczka, 2010).

\section{Compositional variations in the Szklary holtite}

Of the three known localities for holtite, only the Szklary pegmatite has Nb-bearing and Ti-bearing holtite in addition to Ta-bearing holtite. A complete set of spot EMP analyses of the Szklary holtite and dumortierite is presented in Table 1 (Table $1 a$, containing all the data has been deposited with the editor and available from www.minersoc.org/pages/e_journals/ dep_mat_mm.html; a representative selection of these data are given in Table $1 b$ ): (1) homogeneous holtite WPH; $(2-5)$ holtite richest in Ta, $\mathrm{Nb}$, Ti or Sb in the zoned crystals; $(6,7)$ holtite overgrown by As- and Sb-bearing dumortierite (Fig. 2c); (8) As- and Sb-bearing dumortierite and (9) a dumortierite-like phase containing negligible $\mathrm{Ta}, \mathrm{Nb}$ and $\mathrm{Ti}$, as well as more $\mathrm{Sb}+\mathrm{As}$ than $\mathrm{Si}$ ('X-phase'). The dumortierite-like phase is found as a few tiny inclusions not exceeding $20 \mu \mathrm{m}$ across in quartz (Fig. 2d). It has a composition suggesting a relationship with dumortierite, but we do not yet have crystallographic data to confirm this suggestion.

The Szklary holtite varies widely considering $\mathrm{Ta}, \mathrm{Nb}$ and $\mathrm{Ti}$ amounts substituting for $\mathrm{Al}$ at the $\mathrm{Al}(1)$ site (Fig. 3), and in occupancy of the (Sb, As) sites (Fig. 4). This compositional heterogeneity is evident in the majority of holtite crystals, which show a distinct zoning with a core formed by a Ta-bearing variety surrounded by a rim of a Nb-bearing variety a few micrometers wide. There are also dark grey streaks up to $5 \mu \mathrm{m}$ wide of Ti-bearing holtite located within the core or along the core/rim boundary. Holtite without visible compositional zoning was found in only a few aggregates that are generally composed of very thin acicular to asbestiform crystals.

Figure $4 a$ shows the relationship between $\mathrm{Sb}+\mathrm{As}$ and $\mathrm{Si}$, which refers only to occupancy of the $\mathrm{Si}$ and $\left(\mathrm{Sb}^{3+}, \mathrm{As}^{3+}\right)$ sites, the latter being partially occupied triangular pyramids. The compositions plot close to the line $\mathrm{Si}+\mathrm{As}+\mathrm{Sb}=3$ showing an inverse relationship between the $\mathrm{Si}^{4+}$ content and the $\left(\mathrm{Sb}^{3+}+\mathrm{As}^{3+}\right)$ content, which is consistent with each of the two ( $\mathrm{Sb}, \mathrm{As}$ ) sites being

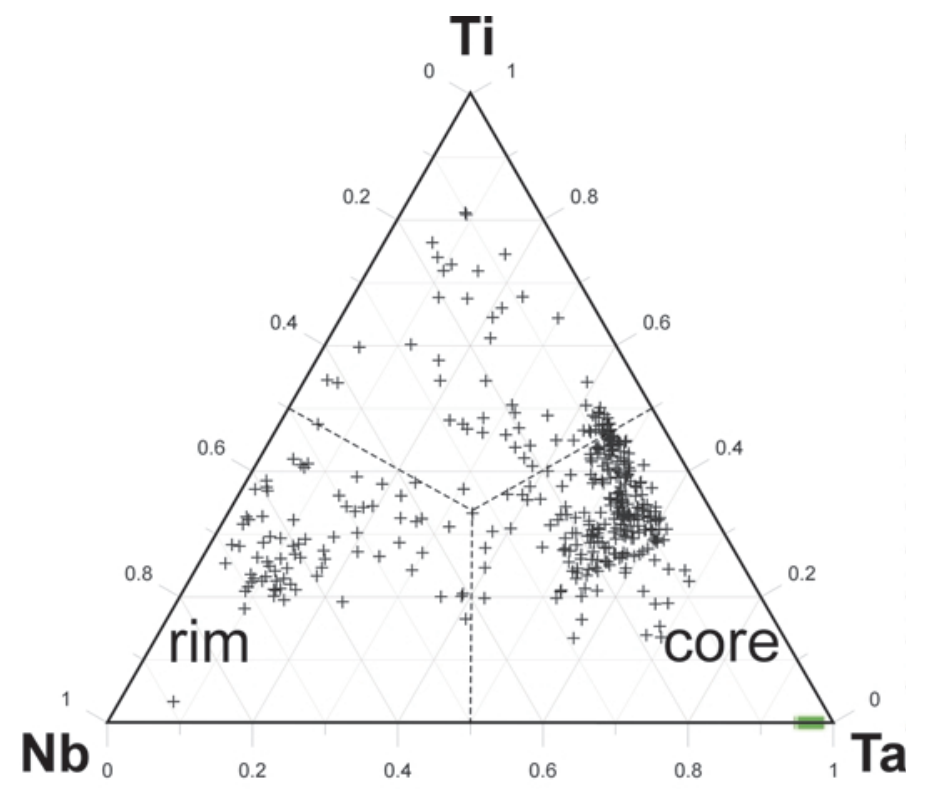

FIG. 3. Composition of the Szklary holtite in the Nb-Ta-Ti ternary system (black crosses - zoned holtite, green crosses clustered near Ta corner - homogeneous WPH holtite). 
TABLE 1(b). Selected compositions of the Szklary holtite, As- and Sb-rich dumortierite, and a dumortierite-like mineral containing negligible $\mathrm{Ta}, \mathrm{Nb}$ and $\mathrm{Ti}$.

\begin{tabular}{|c|c|c|c|c|c|c|c|c|c|}
\hline & $\begin{array}{c}1 \\
\text { WPH-10 }\end{array}$ & $\begin{array}{c}2 \\
\mathrm{Sz} 43 \mathrm{a} / 28\end{array}$ & $\begin{array}{c}3 \\
\text { Sz32/9 }\end{array}$ & $\begin{array}{c}4 \\
\text { Sz34/54 }\end{array}$ & $\begin{array}{c}5 \\
\text { Sz39d/81 }\end{array}$ & $\begin{array}{c}6 \\
\text { Sz5B/1 }\end{array}$ & $\begin{array}{c}7 \\
\mathrm{Sz} 5 \mathrm{~B} / 3\end{array}$ & $\begin{array}{c}8 \\
\text { Sz5B/5 }\end{array}$ & $\begin{array}{c}9 \\
\text { Sz5A/2 }\end{array}$ \\
\hline \multicolumn{10}{|l|}{ Wt.\% } \\
\hline $\mathrm{P}_{2} \mathrm{O}_{5}$ & 0.55 & 0.00 & 0.00 & 0.00 & 0.25 & 0.14 & 0.31 & 0.23 & 0.99 \\
\hline $\mathrm{Nb}_{2} \mathrm{O}_{5}$ & 0.19 & 0.91 & 5.30 & 0.79 & 1.14 & 4.37 & 5.16 & 0.36 & 0.00 \\
\hline $\mathrm{Ta}_{2} \mathrm{O}_{5}$ & 14.66 & 7.73 & 1.06 & 1.12 & 5.33 & 1.57 & 1.15 & 0.21 & 0.00 \\
\hline $\mathrm{SiO}_{2}$ & 20.45 & 17.27 & 17.88 & 21.57 & 15.87 & 19.65 & 19.58 & 23.38 & 12.90 \\
\hline $\mathrm{TiO}_{2}$ & 0.00 & 0.78 & 0.95 & 3.82 & 1.12 & 0.56 & 0.26 & 0.24 & 0.27 \\
\hline $\mathrm{B}_{2} \mathrm{O}_{3} *$ & 5.06 & 5.18 & 5.43 & 5.58 & 5.28 & 5.51 & 5.58 & 5.83 & 5.75 \\
\hline $\mathrm{Al}_{2} \mathrm{O}_{3}$ & 45.85 & 44.61 & 47.55 & 50.07 & 46.11 & 50.44 & 50.84 & 56.09 & 51.88 \\
\hline $\mathrm{Sc}_{2} \mathrm{O}_{3}$ & 0.15 & & & & & 0.21 & 0.25 & 0.17 & 0.20 \\
\hline $\mathrm{As}_{2} \mathrm{O}_{3}$ & 1.98 & 1.70 & 2.14 & 2.88 & 3.30 & 3.90 & 4.39 & 5.56 & 16.81 \\
\hline $\mathrm{Sb}_{2} \mathrm{O}_{3}$ & 5.57 & 18.85 & 18.25 & 11.78 & 19.18 & 10.64 & 10.97 & 6.50 & 10.23 \\
\hline $\mathrm{FeO}$ & 0.00 & 0.16 & 0.22 & 0.12 & 0.27 & 0.75 & 0.45 & 0.38 & 0.20 \\
\hline $\mathrm{H}_{2} \mathrm{O}^{*}$ & 0.53 & 1.32 & 1.32 & 0.99 & 1.49 & 1.01 & 1.08 & 0.91 & 2.16 \\
\hline Total & 94.99 & 98.50 & 100.11 & 98.72 & 99.35 & 98.75 & 100.01 & 99.85 & 101.39 \\
\hline \multicolumn{10}{|c|}{ Atomic contents } \\
\hline $\mathrm{P}^{5+}$ & 0.053 & 0.000 & 0.000 & 0.000 & 0.024 & 0.013 & 0.027 & 0.019 & 0.084 \\
\hline $\mathrm{Si}^{4+}$ & 2.343 & 1.933 & 1.908 & 2.238 & 1.742 & 2.068 & 2.032 & 2.324 & 1.300 \\
\hline $\mathrm{As}^{3+}$ & 0.138 & 0.115 & 0.138 & 0.182 & 0.220 & 0.249 & 0.276 & 0.336 & 1.035 \\
\hline $\mathrm{Sb}^{3+}$ & 0.264 & 0.871 & 0.804 & 0.504 & 0.868 & 0.462 & 0.470 & 0.267 & 0.429 \\
\hline (4) $\mathrm{Al}^{3+}$ & 0.202 & 0.081 & 0.150 & 0.076 & 0.146 & 0.208 & 0.195 & 0.055 & 0.162 \\
\hline$\Sigma T$ & 3.000 & 3.000 & 3.000 & 3.000 & 3.000 & 3.000 & 3.000 & 3.000 & 3.000 \\
\hline $\mathrm{B}^{3+}$ & 1 & 1 & 1 & 1 & 1 & 1 & 1 & 1 & 1 \\
\hline $\mathrm{Nb}^{5+}$ & 0.010 & 0.046 & 0.256 & 0.037 & 0.056 & 0.208 & 0.242 & 0.016 & 0.000 \\
\hline $\mathrm{Ta}^{5+}$ & 0.457 & 0.235 & 0.031 & 0.032 & 0.159 & 0.045 & 0.032 & 0.006 & 0.000 \\
\hline $\mathrm{Ti}^{4+}$ & 0.000 & 0.066 & 0.076 & 0.298 & 0.092 & 0.044 & 0.020 & 0.018 & 0.021 \\
\hline${ }^{(6)} \mathrm{Al}^{3+}$ & 5.989 & 5.803 & 5.829 & 6.048 & 5.816 & 6.048 & 6.025 & 6.515 & 6.000 \\
\hline $\mathrm{Sc}^{3+}$ & 0.015 & & & & & 0.019 & 0.023 & 0.015 & 0.018 \\
\hline $\mathrm{Fe}^{2+}$ & 0.000 & 0.015 & 0.020 & 0.011 & 0.025 & 0.066 & 0.039 & 0.031 & 0.017 \\
\hline (6) vac. & 0.529 & 0.835 & 0.788 & 0.574 & 0.851 & 0.570 & 0.619 & 0.400 & 0.944 \\
\hline $\mathrm{O} 2^{-}$ & 17.197 & 16.028 & 16.116 & 16.628 & 15.823 & 16.578 & 16.508 & 16.796 & 15.092 \\
\hline $\mathrm{OH}^{-}$ & 0.401 & 0.986 & 0.942 & 0.686 & 1.088 & 0.711 & 0.746 & 0.602 & 1.454 \\
\hline \multirow[t]{2}{*}{ vac. } & 0.401 & 0.986 & 0.942 & 0.686 & 1.088 & 0.711 & 0.746 & 0.602 & 1.454 \\
\hline & $\mathrm{HOL}$ & $\mathrm{HOL}$ & $\mathrm{HOL}$ & $\mathrm{HOL}$ & HOL & HOL & HOL & DUM & X-phase \\
\hline
\end{tabular}

Notes: * calculated from stoichiometry. $1-$ WPH holtite, 2-5 - zoned holtite, $6-8-$ holtite overgrown by dumortierite, 9 - X-phase. Abbreviations: HOL - holtite, DUM - dumortierite, X-phase - an unnamed dumortierite-like phase.

too close to the corresponding Si site for either of the $(\mathrm{Sb}, \mathrm{As})$ sites and its corresponding $\mathrm{Si}$ site to be occupied at the same time. The small deviation from the total of $\mathrm{Si}+\mathrm{As}+\mathrm{Sb}$ being 3 is due to the substitution of Si by $\mathrm{P}$ and tetrahedral Al.

Incorporation of $\mathrm{Ti}^{4+}$ is considered to result mostly from the substitution $3 / 4 \mathrm{Ti}+1 / 4 \square \rightarrow \mathrm{Al}$ at the octahedral $\mathrm{Al}(1)$ site, which is analogous to the substitution $3 / 5 \mathrm{Ta}(\mathrm{Nb})^{5+}+2 / 5 \square \rightarrow \mathrm{Al}$, and to a lesser extent from the substitution $\mathrm{Fe}^{2+}+\mathrm{Ti}^{4+} \rightarrow$ 2Al. The proportion of $\mathrm{Ti}[=\mathrm{Ti} /(\mathrm{Ti}+\mathrm{Ta}+\mathrm{Nb})]$ in most samples increases with increasing $\mathrm{Si}$ (Fig. $4 b)$, such that $\mathrm{Ti} /(\mathrm{Ti}+\mathrm{Ta}+\mathrm{Nb})$ reaches a maximum when the amount of $\mathrm{Si}$ at the $\mathrm{T}$ sites exceeds 2.2 a.p.f.u., whereas the proportions of Ta and $\mathrm{Nb}$ taken individually show no such relationship. However, in contrast to the inverse relationship between $\mathrm{As}+\mathrm{Sb}$ and $\mathrm{Si}$, the holtite samples from Greenbushes and Voron'i Tundry ( $\mathrm{H} 1-\mathrm{H} 3$, Groat et al., 2009) do not plot in this trend, suggesting that it cannot be generalized to other holtite samples. 

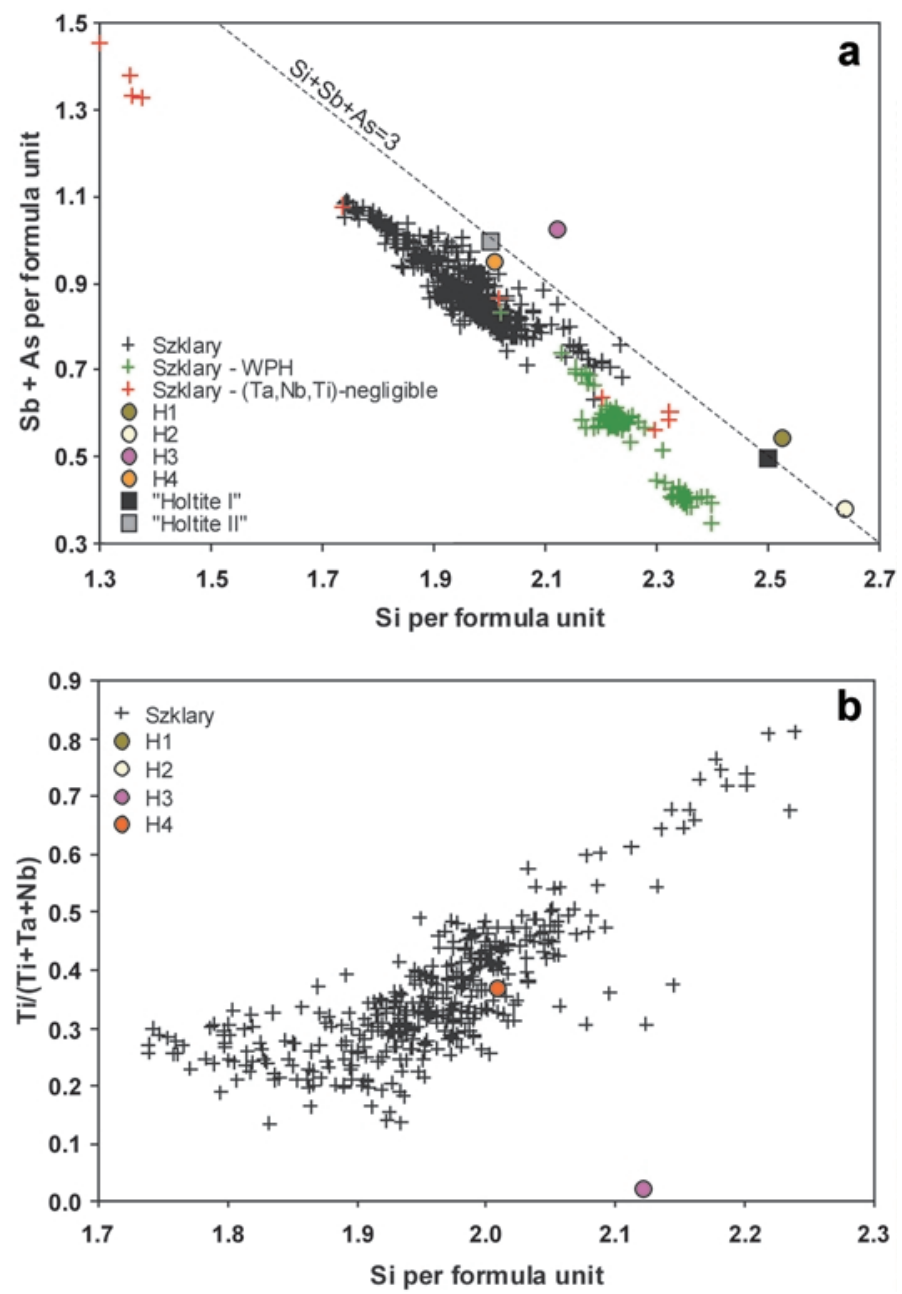

FIG. 4 (this and facing page). Compositional relations in the Szklary holtite and dumortierite: (a) Sb+As (a.p.f.u.) vs. $\mathrm{Si}$ (a.p.f.u.); (b) $\mathrm{Ti} /(\mathrm{Ti}+\mathrm{Ta}+\mathrm{Nb}$ ) vs. $\mathrm{Si}$ (a.p.f.u.); (c) $\mathrm{Ta}+\mathrm{Nb}+\mathrm{Ti}$ (a.p.f.u.) vs. Si (a.p.f.u.); (d) As (a.p.f.u.) vs. $\mathrm{Sb}$ (a.p.f.u.). The data for $\mathrm{H} 1-\mathrm{H} 4$ and idealized 'holtite I' and 'holtite II' are from Groat et al. (2009). H1 and H2 do not plot in the area shown in Fig. $4 b$.

Figure $4 c$ shows the relationship between $\mathrm{Ta}+\mathrm{Nb}+\mathrm{Ti}$ substituting for $\mathrm{Al}$ at the $\mathrm{Al}(1)$ site and the Si content. Compositions of the Szklary holtite and $\mathrm{H} 1-\mathrm{H} 3$ holtites (Groat et al., 2009) plot mostly to the low-Si (left) side of the line marked by 'holtite I' and 'holtite II', with $\mathrm{Ta}+\mathrm{Nb}+\mathrm{Ti}$ decreasing as $\mathrm{Si}^{4+}$ is being replaced by $\mathrm{Sb}^{3+}+\mathrm{As}^{3+}$. The As- and Sb-bearing dumortierite plots as a separate cluster of points with $\mathrm{Ta}+\mathrm{Nb}+\mathrm{Ti} \leqslant$ 0.1 a.p.f.u. and $\mathrm{Si}>2$ a.p.f.u., whereas the dumortierite-like ' $\mathrm{X}$-phase' containing negligible $(\mathrm{Ta}+\mathrm{Nb}+\mathrm{Ti})$ plots at $\mathrm{Si}<1.5$ a.p.f.u., because of extensive substitution of $\mathrm{Si}$ by $\mathrm{As}+\mathrm{Sb}$.
Figure $4 d$ shows two linear trends. Most holtite from Szklary, together with $\mathrm{H} 1-\mathrm{H} 4$ (Groat et al., 2009), plot in a horizontal trend at constant As $\approx$ 0.2 a.p.f.u. with $\mathrm{Sb}$ ranging from 0.2 to 0.9 a.p.f.u. In contrast, (As, Sb)-bearing dumortierite and the dumortierite-like 'X-phase' plot in a nearly vertical trend. The two trends intersect at As $\approx$ $\mathrm{Sb} \approx 0.2$ a.p.f.u. A distinct change in the type of replacement appears in dumortierite crystallized after holtite and in the dumortierite-like 'X-phase' with $\mathrm{As}+\mathrm{Sb}>\mathrm{Si}$, where the As content is always greater than the $\mathrm{Sb}$ content, even if the latter is relatively large. The co-variation of $\mathrm{As}$ and $\mathrm{Sb}$ 

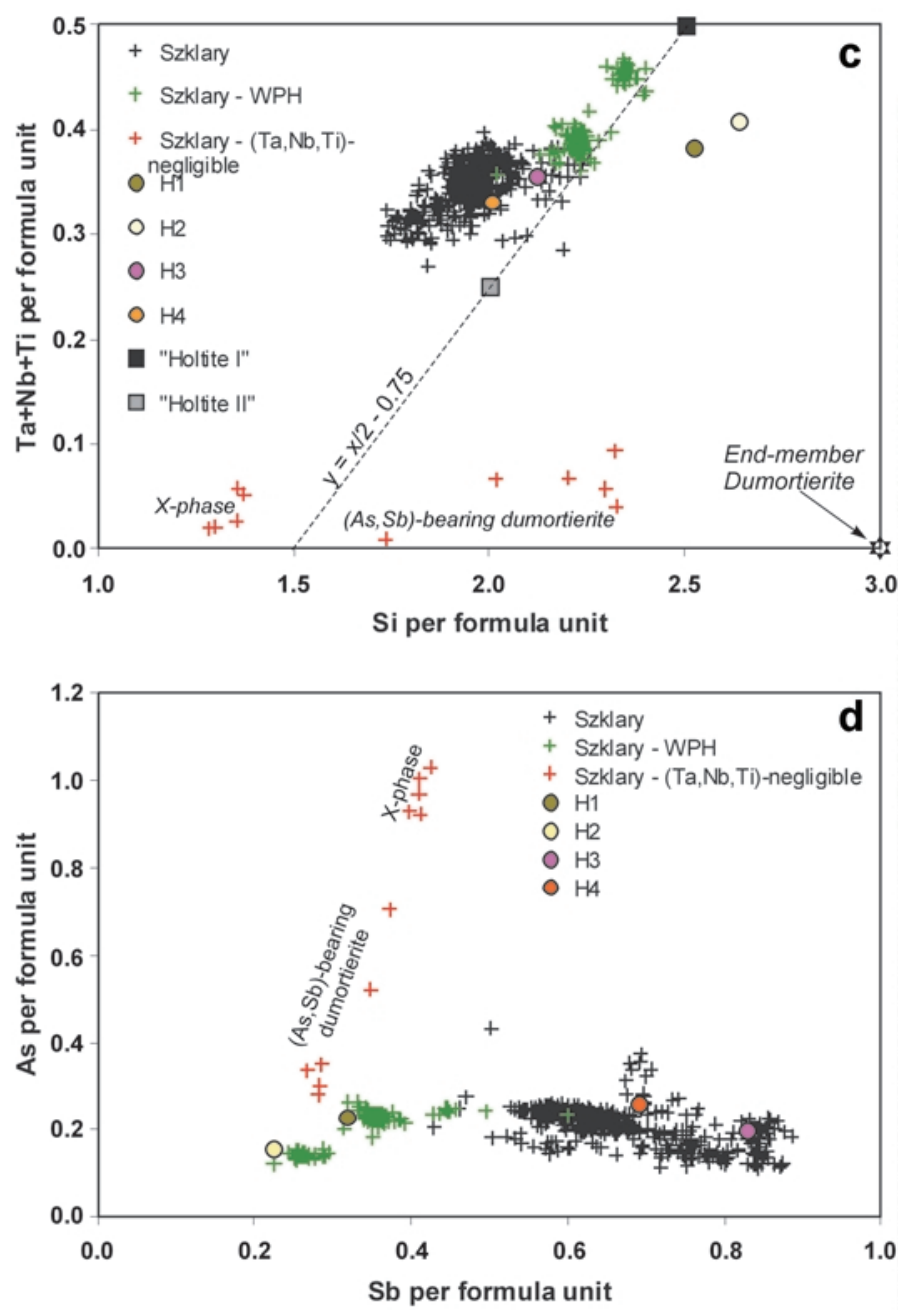

(Fig. 4d) indicates miscibility between dumortierite, the As- and Sb-bearing dumortierite and the $(\mathrm{As}+\mathrm{Sb})$-dominant dumortierite-like 'X-phase' containing negligible $\mathrm{Ta}+\mathrm{Nb}+\mathrm{Ti}$.

The homogeneous Ta-bearing holtite (WPH) $\mathrm{reaches} \mathrm{the} \mathrm{composit}$ io $\mathrm{n}$ $\left(\mathrm{A}_{5.99} \mathrm{Ta}_{0.46} \mathrm{Nb}_{0.01} \mathrm{Sc}_{0.01} \square_{0.53}\right)_{\Sigma 7.00}$ $\mathrm{B}\left(\mathrm{Si}_{2.34} \mathrm{Sb}_{0.26} \mathrm{As}_{0.14} \mathrm{P}_{0.05} \mathrm{Al}_{0.20}\right)_{\Sigma 3.00}$ $\left[\mathrm{O}_{17.20}(\mathrm{OH})_{0.40} \square_{0.40}\right]_{\Sigma 18.00}$ (Table $1 b$ ). This holtite has the greatest $\mathrm{Ta}$ content reported to date: 14.66 wt. $\% \mathrm{Ta}_{2} \mathrm{O}_{5}$ (cf. Greenbushes, 11.24 wt.\% $\mathrm{Ta}_{2} \mathrm{O}_{5}$ : Pryce, 1971 ; 12.06-13.15 wt.\% $\mathrm{Ta}_{2} \mathrm{O}_{5}$ : Groat et al., 2009; Voron'i Tundry, 13.79 and 11.03 wt. $\% \mathrm{Ta}_{2} \mathrm{O}_{5}$ : Kazantsev et al., 2005; 10.93 wt. $\% \mathrm{Ta}_{2} \mathrm{O}_{5}$ : Groat et al., 2009). Given the presence of 0.46 Ta p.f.u., which presumably is located only at the $\mathrm{Al}(1)$ site, and the likelihood for vacancies at the $\operatorname{Al}(2)$, $\mathrm{Al}(3)$ and $\mathrm{Al}(4)$ sites, it is possible that $\mathrm{Ta}>\mathrm{Al}$ and $\mathrm{Ta}>$ vacancy at the $\mathrm{Al}(1)$ site, i.e. Ta is the dominant occupant, which has not been reported previously in holtite. However, the dominance of $\mathrm{Ta}$ at $\mathrm{Al}(1)$ can be demonstrated only by refinement of the crystal structure of the WPH holtite. In any case, this Ta content exceeds $75 \%$ of the maximum possible, because charge balance constrains substitution of $\mathrm{Al}^{3+}$ by $\mathrm{Ta}^{5+}$ or $\mathrm{Nb}^{5+}$ at the $\mathrm{Al}(1)$ site to $0.6(\mathrm{Ta}+\mathrm{Nb})$ a.p.f.u (Groat et al., 2009).

Compositions of Ta-bearing holtite forming the core of zoned crystals vary from a Ta-rich composition $\left(\mathrm{Al}_{5.80} \mathrm{Ta}_{0.23} \mathrm{Ti}_{0.07} \mathrm{Nb}_{0.06}\right.$ 
$\left.\mathrm{Fe}_{0.01}^{2+} \square_{0.83}\right)_{\Sigma 7.00} \mathrm{~B}\left(\mathrm{Si}_{1.93} \mathrm{Sb}_{0.87} \mathrm{As}_{0.12} \mathrm{Al}_{0.08}\right)_{\Sigma 3.00}$ $\left[\mathrm{O}_{16.03}(\mathrm{OH})_{0.99} \square 0.99\right]_{\Sigma 18.00}$ to compositions with $\mathrm{Ta}$ only slightly dominant over $\mathrm{Nb}$ or $\mathrm{Ti}$. With a further decrease in Ta, compositions become Tidominant in tiny streaks within the core or locally on the core/rim margin, and $\mathrm{Nb}$-dominant in the rim. The maximum of $7.73 \mathrm{wt} . \% \mathrm{Ta}_{2} \mathrm{O}_{5}(0.23 \mathrm{Ta}$ a.p.f.u.) in the cores of zoned crystals is distinctly smaller than that in WPH. The Ta-bearing holtite richest in $\mathrm{Sb}+\mathrm{As}$ contains 19.18 wt. $\% \mathrm{Sb}_{2} \mathrm{O}_{3}$ and 3.30 wt. $\% \quad \mathrm{As}_{2} \mathrm{O}_{3}$, reaching the composition $\left(\mathrm{Al}_{5.82} \mathrm{Ta}_{0.16} \mathrm{Ti}_{0.09} \mathrm{Nb}_{0.06} \mathrm{Fe}_{0.02}^{2+} \square 0.85\right)_{\Sigma 7.00}$ $\mathrm{B}\left(\mathrm{Si}_{1.74} \mathrm{Sb}_{0.87} \mathrm{As}_{0.22} \mathrm{Al}_{0.15} \mathrm{P}_{0.02}\right)_{\Sigma 3.00}$ $\left[\mathrm{O}_{15.82}(\mathrm{OH})_{1.09} \square_{1.09}\right]_{\Sigma 18.00}$, with more $\mathrm{Sb}$ or $\mathrm{Sb}+$ As than reported in any holtite to date.

The Nb-bearing variety contains up to 5.30 wt. $\% \quad \mathrm{Nb}_{2} \mathrm{O}_{5}, \quad\left(\mathrm{Al}_{5.83} \mathrm{Nb}_{0.26} \mathrm{Ti}_{0.08} \mathrm{Ta}_{0.03}\right.$ $\left.\mathrm{Fe}_{0.02}^{2+} \square 0.79\right)_{\Sigma 7.00} \mathrm{~B}\left(\mathrm{Si}_{1.91} \mathrm{Sb}_{0.80} \mathrm{As}_{0.14} \mathrm{Al}_{0.15}\right)_{\Sigma 3.00}$ $\left[\mathrm{O}_{16.12}(\mathrm{OH})_{0.94} \square_{0.94}\right]_{\Sigma 18.00}$, whereas the Tibearing variety contains up to 3.82 wt.\% $\mathrm{TiO}_{2},\left(\mathrm{Al}_{6.05} \mathrm{Ti}_{0.30} \mathrm{Nb}_{0.04} \mathrm{Ta}_{0.03} \mathrm{Fe}_{0.01}^{2+} \square_{0.57}\right)_{\Sigma 7.00}$ $\mathrm{B}\left(\mathrm{Si}_{2.24} \mathrm{Sb}_{0.50} \mathrm{As}_{0.18} \mathrm{Al}_{0.08}\right)_{\Sigma 3.00}$ $\left[\mathrm{O}_{16.63}(\mathrm{OH})_{0.69} \square_{0.69}\right]_{\Sigma 18.00}$, comparable with the maximum $\mathrm{Ti}$ content reported in dumortierite, $\sim 0.33$ Ti a.p.f.u. (Huijsmans et al., 1982).

As- and Sb-bearing dumortierite forming a rim around the Nb-bearing holtite core has the composition: $\left(\mathrm{Al}_{6.52} \mathrm{Fe}_{0.03}^{2+} \mathrm{Nb}_{0.02} \mathrm{Ti}_{0.02} \mathrm{Ta}_{<0.01}\right.$ $\left.\mathrm{Sc}_{0.01} \square_{0.40}\right)_{\Sigma 7.00} \mathrm{~B}\left(\mathrm{Si}_{2.32} \mathrm{As}_{0.34} \mathrm{Sb}_{0.27} \mathrm{Al}_{0.05}\right.$ $\left.\mathrm{P}_{0.02}\right)_{\Sigma 3.00}\left[\mathrm{O}_{16.80}(\mathrm{OH})_{0.60} \square_{0.60}\right]_{\Sigma 18.00}$. However, inclusions disseminated around the crystal contain up to $0.71 \mathrm{As}$ a.p.f.u. and $0.50 \mathrm{Sb}$ a.p.f.u., more than reported previously in dumortierite (e.g. Cempírek et al., 2010). Lastly, (As, Sb)-dominant dumortierite-like 'X-phase' contains up to 16.81 wt. $\% \mathrm{As}_{2} \mathrm{O}_{3}$ and 10.23 wt. $\% \mathrm{Sb}_{2} \mathrm{O}_{3}$, but negligible $\mathrm{Ta}$ and $\mathrm{Nb},\left(\mathrm{Al}_{6.00} \mathrm{Ti}_{0.02} \mathrm{Fe}_{0.02}^{2+}\right.$ $\left.\mathrm{Sc}_{0.02} \square 0.94\right)_{\Sigma 7.00} \mathrm{~B}\left(\mathrm{Si}_{1.30} \mathrm{As}_{1.04} \mathrm{Sb}_{0.43}\right.$ $\left.\mathrm{Al}_{0.16} \mathrm{P}_{0.08}\right)_{\Sigma 3.00}\left[\mathrm{O}_{15.09}(\mathrm{OH})_{1.45} \square_{1.45}\right]_{\Sigma 18.00}$, i.e. $\mathrm{As}+\mathrm{Sb}>\mathrm{Si}$.

The full range of $\mathrm{Sb}^{3+}+\mathrm{As}^{3+}$ for $\mathrm{Si}^{4+}$ substitution in the Szklary holtite, $\sim 0.35$ to 1.09 a.p.f.u., suggests an extensive solid solution between ( $\mathrm{Sb}, \mathrm{As}$ )-poor and (Sb,As)-rich holtite (Fig. 4a). This range is wider than that between 'holtite I' ( $\mathrm{Si}=2.50$ a.p.f.u., $\mathrm{Sb}+\mathrm{As}=0.50$ a.p.f.u. $)$ and 'holtite II' ( $\mathrm{Si}=2.0$ a.p.f.u., $\mathrm{Sb}+\mathrm{As}=1.0$ a.p.f.u.; Groat et al., 2009), i.e. our compositional data based on 500 spot analyses of holtite from the Szklary dyke show no evidence for clustering of holtite compositions around compositions corresponding to 'holtite I' and 'holtite II' (Voloshin et al., 1987; Voloshin and Pakhomovskiy, 1988). Although the homogeneous Ta-bearing holtite
WPH has compositions closer to 'holtite I' and the zoned holtite has compositions closer to 'holtite II', the compositions of all the holtite analysed cover almost the full range of possible holtite composition. As noted by Groat et al. (2009), a limited number of localities for holtite and a small number of holtite analyses from any one occurrence could give the illusion of clustering. Evolution of holtite composition in terms of $\mathrm{Sb}^{3+}+\mathrm{As}^{3+}$ substitution for $\mathrm{Si}^{4+}$ is instead a reflection of geochemical evolution of the pegmatite melt from which holtite crystallized.

In summary, our data provide further evidence for miscibility between phases identified as holtite and phases identified as dumortierite, and that the distinction between the two minerals is even more blurred than earlier thought. We have arbitrarily called a phase holtite if $\mathrm{Ta}+\mathrm{Nb}+\mathrm{Ti}>0.25$ a.p.f.u. and dumortierite if $\mathrm{Ta}+\mathrm{Nb}+\mathrm{Ti}<0.1$ a.p.f.u. because of the gap in $\mathrm{Ta}+\mathrm{Nb}+\mathrm{Ti}$ contents evident in Fig. 4c. However, we realize that some dumortierite from other localities, e.g. Norway (Huijsman et al., 1982), contain enough Ti to be called "holtite" using this criterion. Groat et al. (2009) concluded that a more precise definition of holtite and its distinction from dumortierite awaited detailed study of both minerals and that differences in diffraction behaviour need to be considered. Despite the large number of analyses presented here, we concur that it is still premature to propose new definitions of these two minerals, a prerequisite for which are systematic crystallographic studies.

\section{Origin of holtite in the Szklary pegmatite}

Crystallization of holtite in the Szklary pegmatite as a primary $\mathrm{Ta}-\mathrm{Ti}-\mathrm{Nb}$ mineral with columbite$(\mathrm{Mn})$, tantalite-(Mn), stibiotantalite and stibiocolumbite is due to the parental melt being enriched in $\mathrm{Ta}, \mathrm{Nb}, \mathrm{Sb}, \mathrm{As}, \mathrm{Al}$ and $\mathrm{B}$, and to $\mathrm{S}$ fugacity being too low for sulphides such as arsenopyrite and löllingite to form. Both textural relationships among holtite and coexisting minerals, as well as $\mathrm{Ta}-\mathrm{Nb}$ fractionation in the holtite varieties, indicate the following crystallization sequence: Ta-bearing homogeneous holtite WPH $[\mathrm{Ta} /(\mathrm{Nb}+\mathrm{Ta})=0.99-0.95] \rightarrow \mathrm{Ta}-$ bearing holtite forming the core in zoned crystals $[\mathrm{Ta} /(\mathrm{Nb}+\mathrm{Ta})=0.90-0.45] \rightarrow$ Ti-bearing holtite $[\mathrm{Ta} /(\mathrm{Nb}+\mathrm{Ta})=0.85-0.07] \rightarrow$ Nb-bearing holtite forming the rim in zoned crystals $[\mathrm{Ta} /(\mathrm{Nb}+\mathrm{Ta})=$ $0.49-0.03] \rightarrow$ As- and Sb-bearing (Ta,Nb,Ti)poor dumortierite $[\mathrm{Ta} /(\mathrm{Nb}+\mathrm{Ta})=0.15-0.03] \rightarrow$ 
(As and $\mathrm{Sb}$ )-dominant dumortierite-like ' $\mathrm{X}$-phase' containing negligible $\mathrm{Ta}+\mathrm{Nb}+\mathrm{Ti}$. Although $\mathrm{Ti}-$ bearing holtite is found mostly in the core of Tabearing holtite and only locally between Tabearing cores and $\mathrm{Nb}$-bearing rims, its position between the other two varieties in even a few places is sufficient to justify our conclusion that it is intermediate in the crystallization sequence.

Elevated $\mathrm{Ti}$ contents, which have not been reported in holtite from Greenbushes and Voron'i Tundry, could be due to contamination of the Szklary pegmatite-forming melt by ultramafic and mafic wall rocks. In contrast, the rare homogeneous Fe- and Ti-free WPH holtite probably reflects only local changes in melt composition that had not been contaminated by $\mathrm{Mg}, \mathrm{Fe}$, and $\mathrm{Ti}$.

Holtite-stibiocolumbite textural relationships and zoning in the holtite crystals suggest that zoned holtite crystallized with stibiocolumbite following a stage of melt evolution indicated by trend II for columbite-group minerals (Fig. 5). Holtite crystallization began during a stage when the availability of $\mathrm{Ta}$ in the melt reached a maximum, inducing crystallization of the mineral with the highest $\mathrm{Ta} /(\mathrm{Ta}+\mathrm{Nb})$ ratio, i.e. WPH holtite and Ta-bearing holtite in the core in the zoned crystals. Crystallization of Ta-holtite consumed $\mathrm{Ta}$ in the melt and prevented the crystallization of tantalite or stibiotantalite. Subsequently, holtite, columbite-(Mn) and stibiocolumbite, which in places encloses holtite fibres, became progressively richer in $\mathrm{Nb}$, resulting in an anomalous trend that has been reported as trend I for columbite-group minerals in this pegmatite and in a few pegmatites elsewhere (Pieczka, 2010). In summary, $\mathrm{Ta}, \mathrm{Nb}$ and $\mathrm{Ti}$ contents of the zoned holtite provide a record of the availability of these elements in the melt from which it

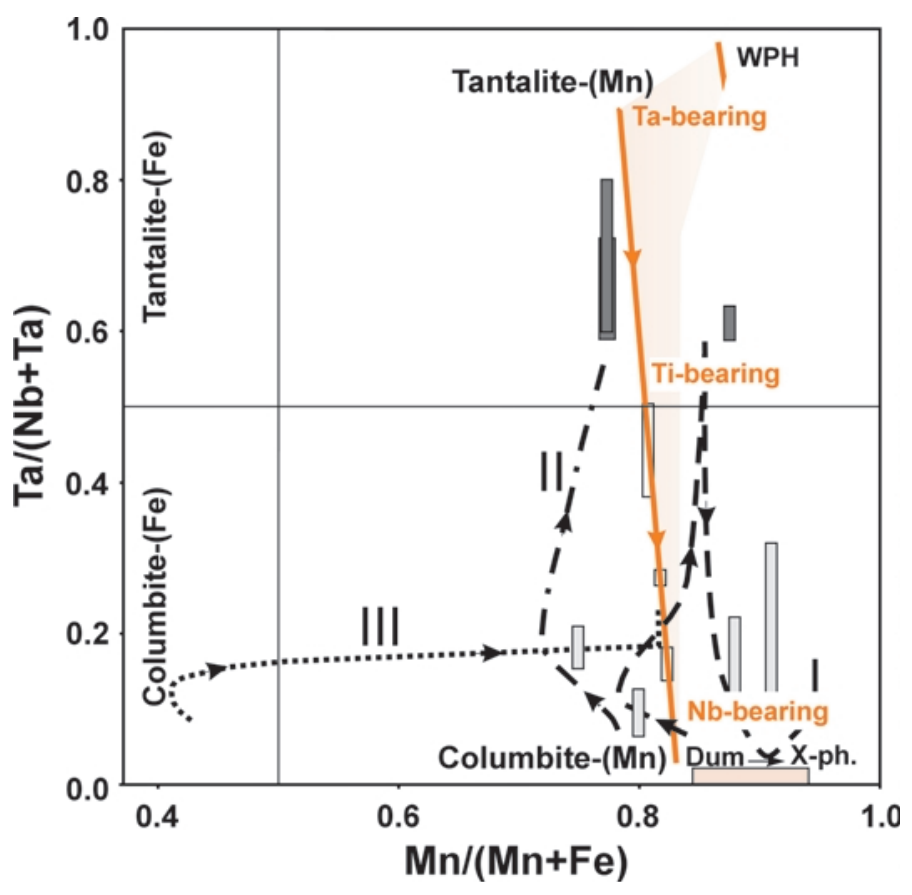

Fig. 5. Paragenetic-chemical diagram showing relationships between holtite and dumortierite and the primary $\mathrm{Nb}-\mathrm{Ta}$ minerals in the Szklary pegmatite in terms of $\mathrm{Mn}-\mathrm{Fe}$ and Ta-Nb fractionation (modified from Pieczka, 2010; fig. 9). Fractionation trend in holtite is denoted by the solid orange line; compositional trends exhibited by the columbitegroup minerals are indicated by the dashed black line (Trend I), dotted-dashed line (Trend II), and dotted line (Trend III); other symbols show the compositional fields of stibiocolumbite coexisting with the CGM (light grey rectangles), stibiotantalite (dark grey rectangles), and stibiocolumbite coexisting with holtite (unfilled rectangles). A crystallization stage for holtite is indicated by the orange area to the right of the Ta-Nb fractionation trend and for As- and Sb-bearing dumortierite passing into the (As,Sb)-dominant dumortierite-like ' $\mathrm{X}$-phase' indicated with an orange rectangle. 
crystallized; this information supplements what can be learned from compositions of the oxides (Pieczka, 2010). Preservation of the fine zoning in holtite is probably due to the slow diffusion of Ta, $\mathrm{Nb}$ and $\mathrm{Ti}$ in this mineral. Although no diffusivity data are available for holtite or dumortierite, the diffusion coefficients for quadrivalent and pentavalent cations are expected to be relatively low (Brady and Cherniak, 2010). There is no need to invoke disequilibrium crystallization to explain the zoning in holtite.

\section{Conclusions}

(1) The compositions of all the holtite varieties in the Szklary pegmatite, which cover a very wide range of possible holtite compositions, including $\mathrm{Nb}$-bearing and Ti-bearing holtite, as well as Tabearing holtite, do not corroborate earlier proposals that holtite analyses clustered around compositions corresponding to 'holtite I' and 'holtite II' (Voloshin et al., 1987; Voloshin and Pakhomovskiy, 1988).

(2) Instead, the substitution of $\mathrm{Si}^{4+}$ by $\mathrm{Sb}^{3+}+\mathrm{As}^{3+}$ at the $\mathrm{Si} / \mathrm{Sb}$ sites and of $\mathrm{Ta}^{5+}$ by $\mathrm{Nb}^{5+}$ or $\mathrm{Ti}^{4+}$ at the $\mathrm{Al}(1)$ site suggest possible solid solutions between: (a) (Sb,As)-poor and ( $\mathrm{Sb}, \mathrm{As}$ )-rich holtite; (b) dumortierite and the unnamed $(\mathrm{As}+\mathrm{Sb})$-dominant dumortierite-like mineral; and (c) Ti-bearing dumortierite and holtite.

(3) Textural relationships between Nb-bearing, Ti-bearing, and Ta-bearing holtite, as well as Asand Sb-bearing dumortierite overgrowing $\mathrm{Nb}$-bearing holtite, suggest the following crystallization sequence for the Szklary pegmatite: Ta-bearing homogeneous holtite $\rightarrow$ Ta-bearing holtite forming the core in zoned crystals $\rightarrow$ Ti-bearing holtite $\rightarrow$ Nb-bearing holtite forming the rim in zoned crystals $\rightarrow$ As- and Sb-bearing, (Ta,Nb,Ti)-poor dumortierite $\rightarrow$ (As and $\mathrm{Sb}$ )dominant dumortierite-like mineral containing negligible $\mathrm{Ta}, \mathrm{Nb}$ and $\mathrm{Ti}$. The last phase is potentially a new mineral species, $\mathrm{Al}_{6} \square \mathrm{B}(\mathrm{Sb}, \mathrm{As})_{3} \mathrm{O}_{15}$ or $\mathrm{Al}_{5} \square_{2} \mathrm{~B}(\mathrm{Sb}, \mathrm{As})_{3}$ $\mathrm{O}_{12}(\mathrm{OH})_{3}$, belonging to the dumortierite group.

\section{Acknowledgements}

We are grateful to W.B. Simmons, G. Raade and P. Uher for their constructive comments and to $\mathrm{L}$. Jeżak and P. Dzierżanowski for their assistance in EMP analyses performed at the University of Warsaw. Special thanks are due to the University of British Columbia for microprobe analyses of WPH holtite. This work was supported financially by AGH - University of Science and Technology, grant no. 11.11.140.158.

\section{References}

Alexander, V.D., Griffen, D.T. and Martin, T.J. (1986) Crystal chemistry of some Fe- and Ti-poor dumortierites. American Mineralogist, 71, 786-794.

Brady, J.B. and Cherniak, D.J. (2010) Diffusion in minerals: An overview of published experimental diffusion data. Pp. 899-920 in: Diffusion in Minerals and Melts (Y. Zhang and D.J. Cherniak, editors). Reviews in Mineralogy \& Geochemistry, 72, Mineralogical Society of America, Chantilly, Virginia, USA.

Cempírek, J., Novák, M., Dolníček, Z., Kotková, J. and Škoda, R. (2010) Crystal chemistry and origin of grandidierite, ominelite, boralsilite, and werdingite from the Bory Granulite Massif, Czech Republic. American Mineralogist, 95, 1533-1547.

Černý, P. and Ercit, T.S. (2005) The classification of granitic pegmatites revisited. The Canadian Mineralogist, 43, 2005-2026.

Franz, G. and Morteani, G. (1984) The formation of chrysoberyl in metamorphosed pegmatites. Journal of Petrology, 25, 27-52.

Fuchs, Y., Ertl, A., Hughes, J.M., Prowatke, S., Brandstätter, F. and Schuster, R. (2005) Dumortierite from the Gföhl unit, Lower Austria. European Journal of Mineralogy, 17, 173-183.

Grew, E.S., Graetsch, H., Pöter, B., Yates, M.G., Buick, I., Bernhardt, H.-J., Schreyer, W., Werding, G., Carson, C.J. and Clarke, G.L. (2008) Boralsilite, $\mathrm{Al}_{16} \mathrm{~B}_{6} \mathrm{Si}_{2} \mathrm{O}_{37}$, and "boron-mullite": compositional variations and associated phases in experiment and nature. American Mineralogist, 93, 283-299.

Groat, L.A., Grew, E.S., Evans, R.J., Pieczka, A. and Ercit, T.S. (2009) The crystal chemistry of holtite. Mineralogical Magazine, 73, 1033-1050.

Hatert, F. and Burke, E.A.J. (2008) The IMA-CNMNC dominant-constituent rule revisited and extended. The Canadian Mineralogist, 46, 717-728.

Hoskins, B.F., Mumme, W.G. and Pryce, M.W. (1989) Holtite, $\left(\mathrm{Si}_{2.25} \mathrm{Sb}_{0.75}\right) \mathrm{B}\left[\mathrm{Al}_{6}\left(\mathrm{Al}_{0.43} \mathrm{Ta}_{0.27} \square 0.30\right)\right.$ $\left.\mathrm{O}_{15}(\mathrm{O}, \mathrm{OH})_{2.25}\right]$ : crystal structure and crystal chemistry. Mineralogical Magazine, 53, 457-463.

Huijsmans, P.P., Barton, M. and van Bergen, M.J. (1982) A pegmatite containing Fe-rich grandidierite, Ti-rich dumortierite and tourmaline from the Precambrian, high-grade metamorphic complex of Rogaland, S.W. Norway. Neues Jahrbuch für Mineralogie Abhandlungen, 143, 249-261.

Kazantsev, S.S., Pushcharovsky, D.Yu., Pasero, M., Merlino, S., Zubkova, N.V., Kabalov, Yu.K. and 
Voloshin, A.V. (2005) Crystal structure of holtite I. Crystallography Reports, 50, 42-47.

Locock, A.J., Piilonen, P., Ercit, T.S. and Rowe, R. (2006) New mineral names. American Mineralogist, 91, 216-224.

Majerowicz, A. and Pin, Ch. (1986) Preliminary trace element evidence for an oceanic depleted mantle origin of the Ślęża ophiolitic complex SW Poland. Mineralogia Polonica, 17, 12-22.

Michalik, R. (2000) Gold in the serpentinite weathering cover of the Szklary massif, Fore-Sudetic Block, SW Poland. Geologia Sudetica, 33, 143-150.

Niśkiewicz, J. (1967) Geological structure of the Szklary Massif (Lower Silesia). Journal of Polish Geological Society, 37, 387-414 (in Polish).

Oliver, G.J.H., Corfu, F. and Krogh, T.E. (1993) U-Pb ages from SW Poland: evidence for a Caledonian suture zone between Baltica and Gondwana. Journal of the Geological Society, 150, 355-369.

Pieczka, A. (2000) A rare mineral-bearing pegmatite from the Szklary serpentinite massif, the ForeSudetic Block, SW Poland. Geologia Sudetica, 33, $23-31$.

Pieczka, A. (2007) Blue dravite from the Szklary pegmatite, Lower Silesia, Poland. Mineralogia Polonica, 32, 209-218.

Pieczka, A. (2010) Primary Nb-Ta minerals in the Szklary pegmatite, Poland: new insights into controls of crystal chemistry and crystallization sequences. American Mineralogist, 95, 1478-1492.

Pieczka, A. and Kraczka, J. (1996) X-ray and Mössbauer study of black tourmalines (schorls) from Szklary (Lower Silesia, Poland). Mineralogia Polonica, 27, 33-40.

Pieczka, A. and Marszałek, M. (1996) Holtite - the first occurrence in Poland. Mineralogia Polonica, 27, $3-8$.

Pouchou, J.L. and Pichor, F. (1985) "PAP" (phi-rho-z) procedure for improved quantitative microanalysis. Pp. 104-106 in: Microbeam Analysis. San Francisco Press, San Francisco, California, USA.

Pryce, M.W. (1971) Holtite: a new mineral allied to dumortierite. Mineralogical Magazine, 38, 21-25.

Sorbier, L., Rosenberg, E. and Merlet, C. (2004) Microanalysis of porous materials. Microscopy and Microanalysis, 10, 745-752.

Timmermann, H., Parrish, R.R., Noble, S.R. and Kryza, R. (2000) New U-Pb monazite and zircon data from the Sudetes Mountains in SW Poland; evidence for a single-cycle Variscan Orogeny. Journal of the Geological Society, 157, 265-268.

van Breemen, O., Bowes, D.R., Aftalion, M. and Żelaźniewicz, A. (1988) Devonian tectonothermal activity in the Sowie Góry gneissic block, Sudetes, southwestern Poland: evidence from $\mathrm{Rb}-\mathrm{Sr}$ and $\mathrm{U}-\mathrm{Pb}$ isotopic studies. Journal of the Polish Geological Society, 58, 3-10.

Voloshin, A.V. and Pakhomovskiy, Ya.A. (1988) Mineralogy of Tantalum and Niobium in RareMetal Pegmatites. Nauka, Leningrad, Russia (in Russian).

Voloshin, A.V., Gordienko, V.V., GelmanYe.M., Zorina, M.L., Yelina, N.A., Kul'chitskaya, K.A., Men'shikov, Yu.P., Polezhayeva, L.I., Ryzhova, P.I., Sokolov, P.B. and Utochkin, G.I. (1977) Holtite (first find in SSSR) and its relationship with other tantalum minerals in rare-metal pegmatites. Novyye Mineraly i Piervyye Nakhodki v SSSR, 106, 337-347 (in Russian).

Voloshin, A.V., Pakhomovskiy, Ya.A. and Zalkind, O.A. (1987) An investigation of the chemical composition and IR-spectroscopy of holtite. In: Mineral'nyye Assotsiatsii $i$ Mineraly Magmaticheskikh Kompleksov Kol'skogo Polyostrova. Apatity, Kol'skiy Filial AN SSSR, 14-34 (in Russian).

Żelaźniewicz, A. (1987) Tectonic and metamorphic evolution of the Góry Sowie, Sudetes Mts, SW Poland. Journal of the Polish Geological Society, 57, 203-348 (in Polish, summary in English).

Żelaźniewicz, A. (1990) Deformation and metamorphism in the Góry Sowie gneiss complex, Sudetes, SW Poland. Neues Jahrbuch für Geologie und Paläontologie Abhandlungen, 179, 129-157. 
